\title{
POSTOJE K AUTOEVALUACI ŘEDITELU゚ ZÁKLADNÍCH A STŘEDNÍCH ŠKOL V ČR
}

\author{
MARTIN CHVÁL, LUCIE PROCHÁZKOVÁ, KAREL ČERNÝ
}

\begin{abstract}
Anotace: $V$ rámci projektu MŠMT Cesta ke kvalitě bylo realizováno dotazníkové šetření mezi řediteli základních a středních škol. Dotazník obsahoval postojové otázky zaměřené na procesy autoevaluace na školách. Na základě faktorové analýzy bylo identifikováno 5 postojových faktorů k autoevaluaci: smysluplnost, zbytečnost, bezradnost, strach, percepce prístupu externích orgánů ČŠl a zřizovatele. Byla identifikována souvislost těchto faktorů se zkušeností škol s autoevaluací měřenou počtem dosud realizovaných cyklů. Nejsilněji je na nárůst zkušenosti vázáno vnímání smysluplnosti a pokles bezradnosti.
\end{abstract}

Klíčová slova: autoevaluace, vlastní hodnocení školy, faktorová analýza, postoje kautoevaluaci, dotazníkové šetření

\begin{abstract}
The project of MŠMT "Pathway to Quality" has performed a questionnaire inquiry among headmasters of basic and secondary schools. The respective questionnaire included attitude questions aimed at self-evaluation processes at schools. Following a factor analysis 5 attitude self-evaluation factors have been identified: meaningfulness, uselessness, helplessness, fear, perception of the approach of external bodies of ČS̆I and the school authority. It has identified the link between these factors and the school practice with the self-evaluation measured by the number of the implemented cycles. The strongest link to the increased experience relates to the perception of meaningfulness and to the decrease of helplessness.
\end{abstract}

Key words: self-evaluation, school self-evaluation, factor analysis, position to self-evaluation, questionnaire inquiry

\section{1 ÚVOD}

Českým školám byla v roce 2004 udělena školským zákonem (Zákon č. 561/2004 Sb.) poprvé $v$ historii povinnost realizovat vlastní hodnocení, zpracovávat zprávu o něm, vést ji jako povinnou dokumentaci školy a předkládat ji České školní inspekci. Tomu předcházely diskuse $v 90$. letech minulého století o tom, jak v nových podmínkách zajistit kvalitu decentralizovaného vzdělávacího systému. Diskuse vyústily $\checkmark$ roce 2001 ve vznik strategického dokumentu Národní program rozvoje vzdělávání v České republice (Bílá kniha), ve kterém byla pojmenována potřeba přenesení zajištění kvality škol, včetně její kontroly, na ně samotné. Následovalo legislativní ukotvení ve zmíněném školském zákoně. Paralelně s těmito diskusemi a legislativ- 
ními dopady vznikly v českých podmínkách dosud ojedinělé publikační opory pro práci škol: V roce 1996 Průcha publikoval odborně laděnou Pedagogickou evaluaci, v roce 1998 Rýdl a kol. praktičtěji laděnou př́ručku Sebehodnocení školy - Jak hodnotit kvalitu školy. Až v druhé polovině prvního desetiletí století současného po uzákonění povinnosti vlastního hodnocení vznikají publikace systematičtější k danému tématu (Vaštatková 2006 či překlad Macbeath a kol. 2006) a rozšiřuje se spektrum publikací či elektronických zdrojů nabízejících i určitou metodickou podporu (Metodický portál Výzkumného ústavu pedagogického - www.rvp.cz). Vedle těchto publikací teoretického rázu či konkrétnější metodické pomoci začíná být sledováno výzkumníky (Prášilová-Vaštatková, 2008, Chvál; Starý 2008), či v rámci organizací přímo řízených MŠMT (Monitoring implementace kurikulární reformy 2008 - souhrnná zpráva. ÚlV, 2008, Konzultační centrum k realizaci ŠVP ZV v regionech - Závěrečná zpráva z pilotní fáze projektu. Praha : NIDV, 2008, Sborník národního projektu Koordinátor, NIDV 2007, Výroční zprávy ČŠl), jak se školy vyrovnávají s těmito novými požadavky, jak je zvládají, prípadně jakou pomoc a podporu by potřebovaly. Detailněji k výsledkům různých výzkumů či analýz zpráv České školní inspekce např. Vaštatková; Prášilová v tomto čísle Orbis Scholae. Závěry z různých těchto šetření lze shrnout tak, že mezi školami jsou velké rozdíly z hlediska jejich zkušeností a potřeby pomoci. Této situaci jistě napomohl stav zvýšené autonomie škol již v 90 . letech minulého století a některými školami pocitovaná potřeba vlastní kontroly a zajištění kvality své činnosti. Takové školy si pak samy vyhledávaly pomoc ve vznikajících publikacích a ojedinělých seminářích v rámci dalšího vzdělávání pedagogických pracovníků k tomuto tématu. Od roku 2006 vznikají metodické opory v rámci státních kurikulárních ústavů (Národní ústav odborného vzdělávání - Starý 2005, Michek 2006, 2008, Výzkumný ústav pedagogický 2007, 2008). Rozhodnutí o systematičtější pomoci školám v oblasti vlastního hodnocení bylo ze strany MŠMT učiněno až v roce 2009 schválením projektu AUTOEVALUACE - Vytváření systému a podpora škol v oblasti vlastního hodnocení aneb Cesta ke kvalitě (více viz www.nuov.cz/ae). Projekt je spolufinancován z ESF a je řešen v rámci Operačního programu Vzdělávání pro konkurenceschopnost (OPVK). Cílovými skupinami projektu jsou všechny druhy a typy škol, které jsou dovoleny OPVK: mateřské školy speciální, základní školy, všechny typy středních škol, základní umělecké školy, konzervatoře, jazykové školy s právem státní jazykové zkoušky. Jedna z aktivit projektu je zaměřena na monitoring procesů autoevaluace 1 na školách na počátku projektu, v jeho průběhu i na konci v roce 2012. Za tímto účelem jsou používány dotazníky, ankety, rozhovory. $V$ této stati jsou představeny výsledky úvodního dotazníkového šetření, které mělo tři cíle:

- zjistit, jaké zkušenosti, potřeby a názory mají ředitelé škol v oblasti vlastního hodnocení,

1 V předloženém textu jsou pokládány pojmy autoevaluace školy a vlastní hodnocení školy za synonyma. Pojem autoevaluace je frekventovaněji užíván v odborné komunitě při tematizování daných procesů na školách, vlastní hodnocení školy záměrně formulované prostřednictvím výhradně českých slov ve školském zákoně již těmto procesům na českých školách dává konkrétněji vymezený a závazný rámec. 
- informovat školy o aktivitách projektu, do kterých se mohou zapojit,

- umožnit školám se na tyto aktivity přihlásit.

\section{REALIZACE ŠETŘENÍ}

Projekt Cesta ke kvalitě zahájil svou činnost v květnu 2009 a hned na červen bylo naplánováno dotazníkové šetření pro všechny typy škol, které mohou být podle pravidel OPVK projektem podpořeny. Dne 12. června 2009 byl rozeslán hromadný e-mail ředitelům všech škol, které mají v rejstř́ku škol uvedenou e-mailovou adresu, s úvodní informací o zahájení a cílech projektu. Součástí e-mailu byl odkaz na webový formulář, jehož prostřednictvím školy mohly vyplnit dotazník, uvedením kontaktních údajů se zaregistrovaly do projektu a vyjádřily svůj zájem o konkrétní aktivity. Zároveň byla v posledním červnovém čísle Učitelských novin uvedena tištěná verze dotazníku, aby na dotazník měly šanci zareagovat také školy, které e-mail nemají nebo nepoužívají.

Dotazníkové šetření a přihlášení do projektu bylo uzavřeno 15. záŕí 2009. Na dotazník odpovědělo 531 škol, což znamená přibližně $8 \%$ návratnost. Relativně nižší návratnost mohla být zpưsobena obdobím školního roku, kdy konec a začátek školního roku jsou ve školách spojeny se zvýšenou administrativou a řadou organizačních povinností. Termín realizace šetření však již nebylo možné změnit vzhledem $\mathrm{k}$ potřebě této aktivity na počátku projektu a nejasnému termínu konečného schválení projektu při jeho plánování. $V$ průběhu projektu a zejména v souvislosti s regionálními konferencemi pořádanými ve všech krajích na podzim roku 2009 se ozvalo ještě několik desítek dalších škol, kterým informace o možnosti přihlásit se do projektu unikla. Mezi kraje s největší návratností patří Praha (13\%) a Ústecký kraj (10\%), ostatní kraje se pohybují kolem $7 \%$.

Nyní stručně představíme vzorek škol, které se do projektu přihlásily. Téměř polovinu vzorku tvoří základní školy, ze středních škol zareagovaly na dotazník nejčastěji střední odborné školy ( $27 \%)$, gymnázia (9\%). Co se týče typu škol podle zřizovatele, 91 \% škol tvoří školy veřejné (státní), 7 \% zastupují školy soukromé (1 \% jsou školy církevní). Kategorie velikosti škol podle počtu žáků je rozdělena do několika intervalů, $42 \%$ škol se nachází v intervalu středně velkých škol s počtem žáků 201-500, podstatnou část (23\%) tvoří velké školy s počtem žáků do 1000. Nezanedbatelné je také $10 \%$ zastoupení malých škol s počtem žáků do 50 .

\section{HLAVNÍ VÝZKUMNÁ ZJIŠTĚNÍ}

\subsection{POSTOJE ŠKOL K AUTOEVALUACI}

Ke zkoumání postojů škol k autoevaluaci byla zkonstruována baterie čítající 15 položek, která byla opatřena čtyřbodovou škálou pro měření intenzity daného 
postoje (viz dále). Prvotní sada položek byla vytipována autory tohoto článku s pomocí dalších spolupracovníků z projektu Cesta ke kvalitě. Pozornost byla zaměřena na položky vztahující se ke smysluplnosti, či naopak zbytečnosti autoevaluace, bezradnosti s procesem autoevaluace, obav ze zneužití výsledků a na vnímání přístupu externích orgánů - zřizovatele a České školní inspekce, kteří mají školským zákonem vymezena práva a povinnosti při hodnocení škol a v přístupu k vlastnímu hodnocení školy. Původní sada položek byla pilotována se třemi řediteli s cílem nalézt adekvátní a ředitelům srozumitelné formulace.

Jako optimální východisko analýz těchto položek se ukázala faktorová analýza, resp. s tímto záměrem byla sada položek již konstruována. Explorativní využití faktorové analýzy umožňuje identifikaci obecnějších, latentních či skrytých struktur, které nelze tak snadno odhalit běžnou (deskriptivní, korelační aj.) analýzou jednotlivých položek. $V$ tomto případě nám poodhalí vztah mezi jednotlivými dílčími postoji k vlastnímu hodnocení škol a pomůže je seskupit do menšího počtu nových obecnějších proměnných.

Ve výsledku tedy dochází ke zpřehlednění a k redukci dat; z původních 15 otázek týkajících se nejrůznějších postojů k autoevaluaci jsme po provedení faktorové analýzy získali konečných 5 obecnějších a kompaktnějších postojových faktorů (jde o jakési obecnější roviny či aspekty postojů $k$ autoevaluaci). Ty pak budou v dalších rozborech postojů vstupovat do analýz také jako nové proměnné (explanační využití faktorů). Pro analýzy byl použit statistický software SPSS 12.0.

Prvotním smyslem použití faktorové analýzy je tedy pokus o zpřehlednění a zjednodušení dat jejich redukcí (vysvětlit co největší variabilitu dat s pomocí co nejmenšího množství nových proměnných, tzv. faktorů). Bylo proto spočítáno několik variant řešení (faktorových analýz) s různými - pokud možno s co nejmenšími - počty faktorů2: konkrétně řešení se třemi ( $50 \%$ vyčerpané celkové variance), čtyřmi ( $58 \%)$ a pěti (64\%) faktory. Vždy byla použita metoda hlavních komponent, tedy metoda s kolmými faktory a dále bylo hledáno rotované řešení s podmínkou varimax. Kromě vyšší - a narůstající - celkové vyčerpané variance (každý další faktor vždy přináší nárůst celkové vyčerpané variability, tento nárůst se však s každým dalším faktorem zpomaluje) hrála při výběru konečného řešení hlavně jeho interpretační smysluplnost a jasná vnitřní konzistence (tedy prínos pro porozumění a lepší vhled na empirická data). Následuje zevrubný přehled výsledků jednotlivých řešení, zejména s uvedením jejich kladů a záporů.

- Řešení se třemi faktory nabídlo obdobu rozlišení faktoru smysluplnosti, bezradnosti a strachu. Řada položek ( 5 z celkových 10$)$ však poměrně silně sytila hned několik faktorů najednou (chovaly se $v$ daném řešení značně nejednoznačně), nebo naopak žádný z nich.

- Alternativa se čtyřmi faktory přinesla navíc - kromě mírně vyšší celkové

2 Data z použité 15položkové baterie postojových otázek jsou pro užití faktorové analýzy velmi vhodná. Bartlettův test sféricity vyvrací hypotézu, že je korelační matice maticí jednotkovou (Sig. $<0,001)$, vztahy mezi jednotlivými proměnnými tedy existují. KMO test míry adekvátnosti výběru $(0,798)$ pak jasně ukazuje na velmi dobrou vhodnost použití faktorové analýzy na tato data. 
vyčerpané variance - ještě rozlišení nového specifického faktoru „percepce postoje k autoevaluaci ze strany ČŠl a zřizovatele“. Stále však zůstávalo několik položek, které nesytily žádný faktor, př́padně ty, které svou vahou přispívaly hned do několika faktorů zároveň.

- Řešení s pěti faktory pak přineslo zásadní „přidanou hodnotu“ v podobě nového faktoru "zbytečnosti“ (či "neefektivity") autoevaluace. Kromě toho, že jde o interpretačně jasné řešení, také se do něj statisticky nejlépe a jednoznačně zapojily všechny dotazníkové postojové položky. Další výhodou této alternativy je také skutečnost, že jednotlivé faktory jsou poměrně vyvážené, každý z nich vysvětluje po rotaci varimax přibližně stejně velkou část celkové variability (v rozmezí od $18 \%$ do $11 \%$ celkové variance); žádný faktor není výrazně dominantní, nepozorujeme však ani žádné faktory marginální či „zbytkové", což je častý případ faktorových analýz s větším počtem faktorů ( $v$ tomto prípadě se šesti a více faktory).

Tento postupný a kumulativní postup faktorové analýzy transparentně ukázal, že výsledné řešení je velmi stabilní a spolehlivé (jeho zárodky bylo možné pozorovat již v řešení se třemi a poté čtyřmi faktory, která nejsou interpretačně diametrálně odlišná od řešení s pěti faktory).

O stabilitě a statistické robustnosti zvoleného řešení svědčí také to, že interpretačně prakticky stejného výsledku faktorové analýzy se podařilo dosáhnout jak (a) při analýzách, kdy byly zahrnuty i odpovědi "nevím/nedokážu posoudit" (a to do středu škály), tak (b) také při analýzách, kdy byly odpovědi „nevím/nedokážu posoudit" nahrazeny aritmetickým průměrem odpovědí na danou otázku (standardní postup, software SPSS sám tuto možnost nabízí), a dokonce i při (c) analýzách, kdy byli respondenti odpovídající „nevím/nedokážu posoudit“" zcela vyřazeni z dalších výpočtů.

Faktorová analýza ponechává prostor pro výzkumníky a jejich originalitu a vynalézavost zejména ve fázi interpretace a pojmenovávání jednotlivých faktorů (tento postup však Ize ověřit a zkontrolovat s pomocí matice faktorových zátěží, viz tabulka 1). I tento proces však má svou jasnou logiku, pojmenovávání nových faktorů je vedeno snahou zobecnit společný význam jednotlivých otázek, jež daný faktor sytí (tj. vyjádřit, co mají jednotlivé postoje z daného faktoru společného). Takto jsme identifikovali následujících pět faktorů: zbytečnosti, bezradnosti, percepce Čšl a zrizovatele, smysluplnosti a strachu. 
Tabulka 1: Postoje k autoevaluaci (faktorová analýza, matice faktorových zátěží)

\begin{tabular}{|c|c|c|c|c|c|}
\hline \multirow[t]{2}{*}{ Položky sytící jednotlivé faktory } & \multicolumn{5}{|c|}{ Jednotlivé faktory } \\
\hline & 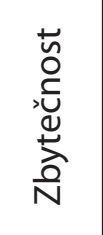 & 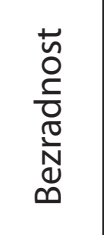 & 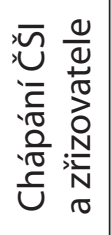 & 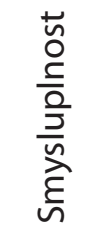 & 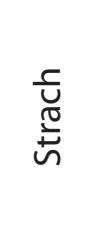 \\
\hline Jde o další administrativní požadavek a zátěž & ,806 &,- 001 &,- 066 &,- 049 & 108 \\
\hline $\begin{array}{l}\text { V procesu AE jsme se nedozvěděli nic, co už } \\
\text { nevíme }\end{array}$ & 799 & ,083 &,- 048 & 129 & , 153 \\
\hline $\begin{array}{l}\text { AE nepřinesla takový efekt v porovnání s tím, } \\
\text { co vyžaduje }\end{array}$ & ,765 & ,159 &,- 112 &,- 144 & , 163 \\
\hline $\begin{array}{l}\begin{array}{l}\text { Realizace AE přispěla k lepší komunikaci s ro- } \\
\text { diči }\end{array} \\
\end{array}$ &,- 560 & ,061 & , 128 & ,391 & ,141 \\
\hline $\begin{array}{l}\text { Nemáme dost znalostí a kvalifikace k opti- } \\
\text { málnímu provedení } A E\end{array}$ &,- 028 & ,858 &,- 074 &,- 100 & 103 \\
\hline Nevím si rady s interpretací výsledků $\mathrm{AE}$ & 039 & ,766 &,- 132 &,- 058 & , 180 \\
\hline $\begin{array}{l}\text { Nedostatek dostupných a spolehlivých ná- } \\
\text { strojů použitelných pro } A E\end{array}$ & , 115 & ,725 &,- 048 &,- 030 & -051 \\
\hline Přístup ČŠI k AE je srozumitelný &,- 099 &,- 074 & ,806 & 099 &,- 091 \\
\hline Přístup zřizovatele k AE je srozumitelný &,- 062 &,- 114 & ,778 &, 135 & ,040 \\
\hline Obáváme se zneužití výsledků $\mathrm{AE}$ & , 178 &, 116 &,- 535 & 281 & 414 \\
\hline $\begin{array}{l}\text { AE jsme začali realizovat dříve, než vznikl le- } \\
\text { gislativní požadavek }\end{array}$ & ,084 &,- 247 & ,092 & ,762 & , 006 \\
\hline $\begin{array}{l}\text { Bez AE si nedokážu představit zkvalitnění } \\
\text { práce školy }\end{array}$ &,- 476 & , 104 & ,111 & ,578 &,- 136 \\
\hline $\begin{array}{l}\text { AE do sboru vnáší strach z kontroly a postihů } \\
\text { při zjištění nedostatků }\end{array}$ & 035 & ,096 &,- 118 & 051 & 825 \\
\hline $\begin{array}{l}\text { Učitelé AE nechápou jako nutné zlo, ale uži- } \\
\text { tečnou aktivitu, přinášející však práci navíc }\end{array}$ &,- 340 &,- 082 & 039 & ,444 &,- 569 \\
\hline Učitelé mají velký zájem o výsledky AE &,- 344 &,- 101 &,- 062 & 450 &,- 509 \\
\hline \% rozptylu & 18 & 13 & 11 & 11 & 11 \\
\hline \% kumulove & 18 & 32 & 42 & 53 & \\
\hline
\end{tabular}

Pozn.: Metoda hlavních komponent, rotované řešení s podmínkou varimax

Podívejme se nyní podrobněji na jednotlivé faktory.

1 Faktor zbytečnosti, nebo snad také faktor neefektivity, je zhruba stejnou měrou (viz hodnota faktorových zátěží v tabulce) sycen těmito postojovými položkami: - Jde o další administrativní požadavek shora, který školám přináší pouze zátěž. 
- V našem procesu autoevaluace jsme se zatím nedozvěděli nic, co už bychom předtím nevěděli.

- Autoevaluace nám nepřináší až takový efekt v porovnání s tím, co si vyžaduje.

Při interpretaci faktoru je $v$ tomto prípadě vhodné přihlédnout také $k$ silným záporným korelacím některých (viz matice faktorových zátěží) postojů s tímto faktorem (zejména: realizace vlastního hodnocení přispěla $\mathrm{k}$ lepší komunikaci $s$ rodiči; bez procesu si nedokážeme představit zkvalitnění fungování školy). Celkově pak daný faktor vysvětluje $18 \%$ celkové variability dat.

2 Faktor bezradnosti vysvětluje zhruba $13 \%$ celkové variability dat a je také poměrně rovnoměrně vytvářen všemi třemi postojovými položkami:

- Nemáme dostatečné znalosti a kvalifikaci, abychom mohli autoevaluaci provádět tak, jak bychom si představovali.

- Nevíme si rady s interpretací výsledků autoevaluace.

- Pocitujeme nedostatek volně dostupných a profesionálně zpracovaných nástrojů (dotazník atd.), které bychom mohli použít k autoevaluaci naší školy.

3 Faktor chápání (percepce) Čšı a zřizovatele vysvětluje asi $11 \%$ celkové variability a je sycen dvěma stejně „vlivnými“ položkami:

- Prístup k autoevaluaci ze strany našeho zřizovatele je pro nás srozumitelný.

- Př́stup k autoevaluaci ze strany ČŠl je pro nás srozumitelný.

Na tomto místě je z hlediska interpretace a pojmenování faktoru vhodné upozornit na poměrně silnou zápornou korelaci faktoru s položkou „obáváme se zneužití výsledků autoevaluace" (nečitelnost postoje Čšl a zřizovatele je tedy do určité míry spjata i s vyšší mírou obav ze zneužití výsledků - čím je naopak postoj těchto dvou institucí jasnější a srozumitelnější, tím jsou také nižší obavy ze strany škol).

4 Faktor smysluplnosti tvoři různou měrou celkem pět postojových otázek a vysvětluje také okolo $11 \%$ celkové variability:

- Autoevaluaci jsme na škole začali realizovat dříve, než vznikl legislativní požadavek (tato položka je s faktorem spjata nejsilněji, viz matice faktorových zátěží).

- Bez autoevaluace si nedokážeme představit zkvalitnění práce školy (tato položka je s faktorem spjata již o něco méně, avšak stále relativně silně).

- Učitelé naší školy nechápou autoevaluaci jako nutné zlo, ale jako užitečnou aktivitu, i když přináší práci navíc.

- Učitelé naší školy mají velký zájem o výsledky autoevaluace (tyto dvě položky sytí faktor zhruba stejně silně).

- Realizace autoevaluace přispěla k lepší komunikaci s rodiči (tato položka do celého faktoru vstupuje nejméně, proto je také její relevance při pojmenovávání faktoru nejnižší, spíše „orientačni"). 
5 Faktor obav, strachu z autoevaluace vysvětluje také okolo $11 \%$ celkové variability a je sycen dvěma položkami:

- Autoevaluace přináší do pedagogického sboru strach z kontroly a postihu při zjištění nedostatků (tato položka je v rámci faktoru dominantní, viz matice faktorových zátěži).

- Obáváme se zneužití výsledků autoevaluace (např. jejich dezinterpretace, nepochopení, vytržení z kontextu ze strany ČŠl, zřizovatele, rodičů).

Tento faktor je zároveň negativně korelován s postojovými otázkami týkajícími se smysluplnosti vlastního hodnocení školy pohledem učitelů (viz učitelé chápou jako užitečnou aktivitu, učitelé se zajímají o výsledky). Je tedy svázán s percepcí toho, jak autoevaluaci vnímají učitelé, poukazuje tak pravděpodobně zejména na strach a obavy na straně pedagogického sboru.

Podívejme se tedy nyní na základní zjištění stran hodnocení autoevaluace na českých školách. Jednotlivé dílčí postoje škol k autoevaluaci pro přehlednost řadíme právě s pomocí logiky identifikovaných pěti základních skupin postojů vzniklých na základě faktorové analýzy. Jde tedy o tematicky a logicky vzájemně související názory (otázky).

\subsubsection{ZBYTEČNOST, NEBO NEEFEKTIVITA AUTOEVALUACE?}

Téměř dvě třetiny škol (59\%) deklarují, že jim autoevaluace nepřináší zas až takový efekt v porovnání s tím, jaké úsilí vyžaduje. Jde tedy o pocit, že se jedná o neefektivně vynaložené úsilí. Zhruba polovina škol (48\%) se pak domnívá, že se v jejím průběhu škola vlastně nedozvěděla nic, čeho by si již nebyla vědoma před samotným autoevaluačním procesem. Výsledky tedy těmto školám - $v$ jejich pohledu nepřinášejí nijak zásadní zjištění.

Třetina škol (33\%) pak autoevaluaci považuje prímo za další administrativní požadavek "shora", který jim přináší pouze zátěž. Zejména toto zjištění je poměrně alarmující a mělo by se stát předmětem dalších analýz a zkoumání.

Celkově vidíme, že většina škol se kloní spíše ke kritice namiřené na neefektivitu celého procesu (nepřináší patřičné výsledky ve srovnání s vynaloženým úsilím, nepřináśí nic, co by škola beztak nevěděla na základě každodenního provozu a běžného nezacíleného monitoringu). Pouze o jedné třetině škol Ize ř́ci, že autoevaluaci chápou jako jednoznačnou zbytečnost a nesmyslnou zátěž. Tyto postoje $k$ autoevaluaci většiny škol se tak mohou potenciálně změnit, pokud bude proces školám přinášet více relevantních a smysluplných výsledků, prípadně se sniží jeho časová, organizační a administrativní náročnost.

Celkově jsme zde identifikovali určité náznaky (reportované zástupci škol) negace a opozice vůči autoevaluaci ze strany pedagogického sboru (nezájem, nutné zlo a nic nepřinášející práce navíc). Tyto postoje se týkají zhruba poloviny škol našeho vzorku a představují patrně jednu z hlavních bariér úspěšné implementace zákona do praxe. 
Graf 1: Postoje škol k autoevaluaci

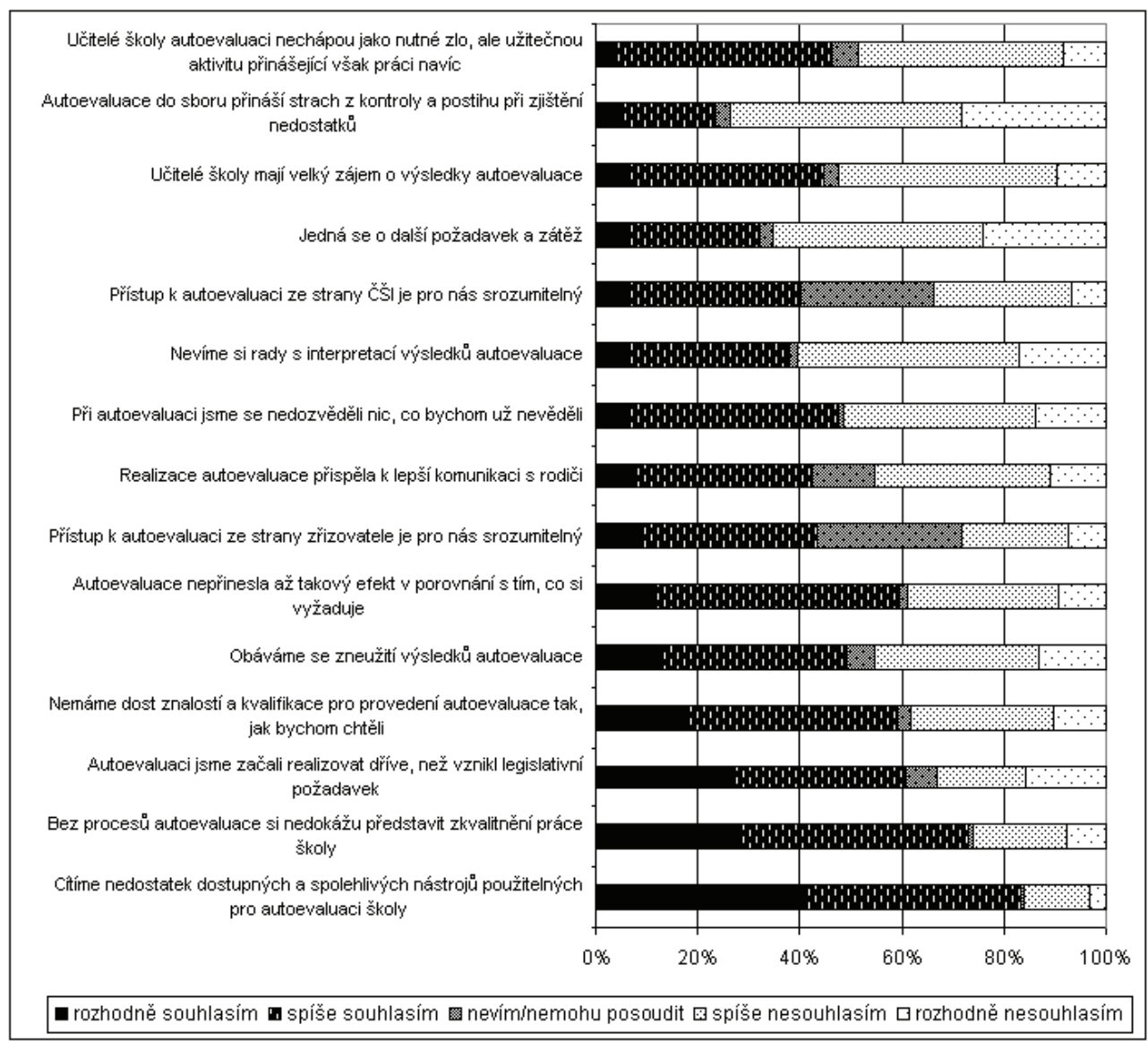

\subsubsection{VYSOKÁ BEZRADNOST ŠKOL}

Školy intenzivně pocitují zejména deficit volně dostupných a spolehlivých evaluačních nástrojů, které by mohly na své škole použít ( $83 \%)$. Ze strany škol tedy existuje vysoká poptávka po profesionálně zpracovaných nástrojích (např. dotazníky). $\vee$ tomto názoru mezi školami panuje relativně vysoký konsenzus (jednotlivé školy se v této otázce nejvíce shodnou) vyjádřený nejmenší mírou variability v odpovědích (směrodatná odchylka $=1,1$ ). To Ize doložit také vůbec nejnižším zastoupením odpovědí „nevím/nedokážu posoudit" (necelé jedno procento odpovědí) v této dílčí otázce.

Mnoho škol také reflektuje nedostatek znalostí, kvalifikace a dovedností pro takové provedení autoevaluace, se kterým by byly spokojené, které by odpovídalo jejich představám (59\%). Jde tedy o sebekritickou reflexi deficitu znalostí a kvalifikace pro optimální provedení autoevaluace na úrovni hlavních aktérů, kteří auto- 
evaluaci - a její jednotlivé fáze - provádějí (tj. zejména ředitelé škol a vedením školy pověření učitelé, ale $\mathrm{v}$ mnoha fázích jde podle námi provedených analýz o celý učitelský sbor).

O něco méně škol - jde však stále o více než třetinu (38\%) - pak také pocituje bezradnost týkající se interpretace výsledků autoevaluačního procesu.

Tato rovina analýzy tedy mj. identifikuje nejen současnou bezradnost škol (její obsah a intenzitu), ale také jejich potřeby metodické podpory autoevaluace. Poukazuje na vysokou poptávku v oblasti expertní podpory a vedení (zejména evaluační nástroje, ale také znalosti a kvalifikace pro správné provádění celého procesu, v menší míre pak i podporu v oblasti interpretace zjištění).

\subsubsection{NEČITELNOST ROLE ZŘIZOVATELE ŠKOL A ČESKÉ ŠKOLNÍ INSPEKCE}

Pro velké množství škol je nečitelný postoj a přístup k autoevaluaci ze strany zřizovatele (obec, krajský úřad), ale také ze strany České školní inspekce. Pouze $43 \%$ škol rozumí prístupu zřizovatele a chápe ho. Podobně pouze $40 \%$ škol chápe přístup inspekce. Přitom méně než každá desátá škola tento postoj chápe „rozhodně" (vesměs se tedy školy uchylují k odpovědi „spíše“, která indikuje menší vyhraněnost názoru na danou otázku). Co je však podstatnější, více než čtvrtina škol na tuto otázku nedokáže vůbec odpovědět („nevím/nedokážu posoudit"), což je vůbec nejvyšší zastoupení takovýchto odpovědí v celém výzkumu. To opět signalizuje nečitelnost a nesrozumitelnost postoje a prístupu k autoevaluaci ze strany obou zmíněných institucí.

Zde jsme identifikovali vysokou nesrozumitelnost zřizovatelů a Čšl. Jako obecné socio-technické doporučení lze formulovat důraz na zlepšení komunikace těchto institucí se školami (např. formou regionálních konferencí realizovaných v rámci projektu Cesta ke kvalitě).

\subsubsection{SMYSLUPLNOST V OČÍCH ŘEDITELU゚ ŠKOL A UČITELU゚}

Naprostá většina škol (celých $73 \%$ ) si bez autoevaluace nedokáže představit zkvalitňování práce školy. Jde tedy z jejich pohledu o klíčovou aktivitu z hlediska budoucího rozvoje školy.

Celé dvě třetiny škol (cca $60 \%$ ) pak deklarují, že s autoevaluací samy začaly ještě před tím, než vznikl legislativní požadavek. Ve velké míře jde právě o ty školy, které ji chápou jako naprosto nezastupitelný proces nutný pro zkvalitňování práce školy (viz výše).

Dále necelá polovina škol (45\%) uvádí, že její učitelé mají velký zájem o výsledky autoevaluace. Mírná většina ( $53 \%$ ) však i tak uvádí, že učitelé o výsledky př́lišný zájem neprojevují.

Podobně necelá polovina ( $46 \%$ ) škol uvádí, že učitelé autoevaluaci chápou jako užitečnou aktivitu - nikoliv jen nutné zlo - která ovšem přináší práci navíc. Avšak zhruba stejné je zastoupení škol, kde údajně učitelé o autoevaluaci uvažují primár- 
ně jako o nutném zlu a práci navíc, která však nic smysluplného a prospěšného nepřináší (48 \%).

\subsubsection{STRACH A OBAVY Z AUTOEVALUACE}

Zhruba polovina škol (49\%) se obává zneužití výsledků autoevaluace školy. Podstatně nižší jsou pak obavy z toho, aby proces autoevaluace nevnesl do pedagogického sboru strach z kontroly a postihů při zjištění nedostatků ( $24 \%)$. V této souvislosti lze doporučit, aby byl tématu možného zneužití výsledků věnován prostor napríklad $v$ připravovaném programu Koordinátor autoevaluace.

\section{2 ČÍM JSOU POSTOJE K AUTOEVALUACI OVLIVNĚNY?}

Další analýzy se budou snažit rozklíčovat, s čím názory na vlastní hodnocení škol souvisí. Půjde zejména o následující možné souvislosti a vztahy: (a) souvislost postojů s dosavadní zkušeností školy s autoevaluací (měřeno počtem celých dosud realizovaných cyklů autoevaluace), (b) krajská diferenciace postojů k autoevaluaci, (c) souvislost postojů a velikosti školy, (d) souvislost postojů a typu školy (např. základní škola, střední odborné učiliště).

\subsubsection{POSTOJE ŠKOL K AUTOEVALUACI SOUVISÍ S POČTEM REALIZOVANÝCH CYKLO̊ AUTOEVALUACE}

V našem vzorku jsou velmi různé školy co do míry zkušenosti s autoevaluací. $\checkmark$ naprosté většině př́padů mají za sebou již alespoň nějakou zkušenost s vlastním hodnocením. Pouze $3 \%$ škol celou autoevaluaci ještě ani jednou neprovedla (jde o 18 škol z našeho vzorku). Většina škol již realizovala jeden nebo dva celé autoevaluační cykly (po zhruba $40 \%$ škol). Dále jsou školy, které již mají za sebou tři, nebo dokonce více celých cyklů (16\%).

Následuje proto analýza souvislostí mezi počtem realizovaných cyklů autoevaluace a postoji k autoevaluaci - vyjádřenými jednak v podobě pěti souhrnných faktorů, jednak podrobněji rozpracovanými v podobě jednotlivých původních otázek (celkem 15). Celý následující výklad hlavních zjištění je však i nadále organizován v logice základních postojů vyjádřených hlavními faktory.

Než se pustíme do prezentace hlavních zjištění, je zapotřebí hned zkraje uvést, že dané analýzy neošetřují směr vztahu mezi postoji a zkušeností škol s autoevaluací. Je docela dobře možné, že se postoje $k$ autoevaluaci mění pod vlivem narůstající zkušenosti s ní. Také však naše data mohou znamenat, že ty školy, které se k vlastnímu hodnocení staví dlouhodobě a primárně kladně, se na základě tohoto postoje do autoevaluačního procesu také častěji pouštějí (ačkoliv to po nich třeba ještě ve své době ani nepožadoval školský zákon). 
Graf 2: Počet realizovaných autoevaluačních cyklů (v \% odpovědí)

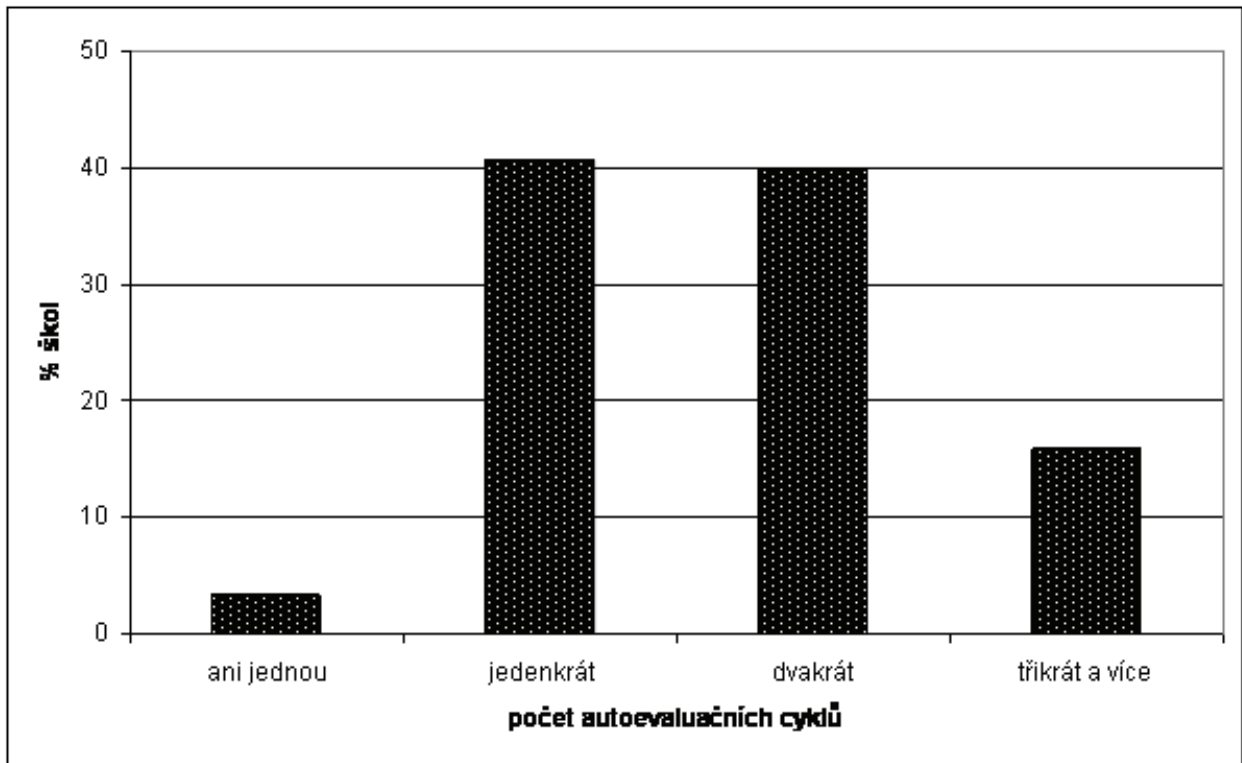

Graf 3: Vývoj postojů v závislosti na počtu realizovaných cyklů autoevaluace (postoje jsou reprezentovány jednotlivými faktory)

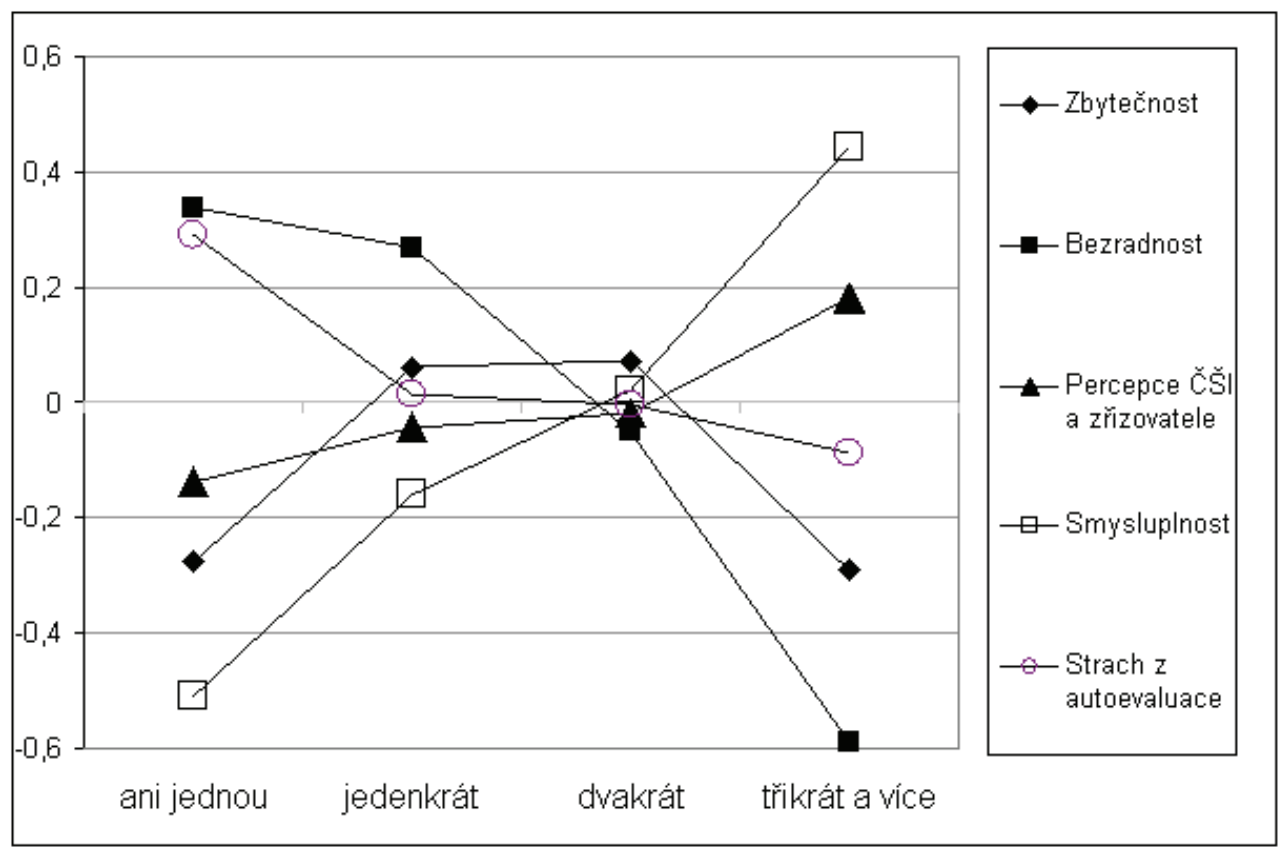

Základní pohled (viz graf 3) naznačuje, že počet realizovaných cyklů s jednotlivými skupinami postojů reprezentovanými danými faktory souvisí. Grafický výstup 
však odkazuje k možným tendencím a vztahům, jejichž spolehlivost je však zapotřebí statisticky ověřit a testovat.

1 Názory na zbytečnost či neefektivnost procesu vlastního hodnocení školy se zlepšují až po absolvování dvou a více celých cyklů autoevaluace. Tento vztah tedy jako jediný nemá lineární průběh. Školy bez jakékoliv zkušenosti s vlastním hodnocením tento proces nepokládají za zbytečný či neefektivní. Školy, které již absolvovaly jeden či dva celé cykly, jsou vưči autoevaluaci poněkud kritičtější pokládají ji za spíše zbytečnou a neefektivní aktivitu (administrativní požadavek a neefektivní zátěž nepřinášející žádné nové poznatky).

Avšak relativně zkušené školy, které již prošly třemi a více cykly, zastávají radikálně odlišný postoj: autoevaluaci již nepokládají za zbytečnou a neefektivní aktivitu. Vzhledem k nelinearitě vztahu a možným logickým důvodům prezentovaného trendu nebyl tento vztah podroben detailnějším statistickým analýzám.

2 Spolu s rostoucí zkušeností škol s vlastním hodnocením výrazně klesá jejich bezradnost ohledně toho, jak by měly autoevaluaci správně provádět (pocitovaný nedostatek dostupných a seriózních nástrojů, nedostatek znalostí a kvalifikace, bezradnost s interpretací výsledků). Tento faktor je ze všech hodnocených faktorů statisticky nejsilněji spjatý s počtem realizovaných cyklů (Spearmanův koeficient korelace $-0,28)$, je statisticky signifikantní (Sig. $<0,001)$ a poměrně lineární.

Opustíme-li "globální" optiku pohledu na problematiku skrze syntetické faktory a podíváme-li se na věc opět podrobnějším pohledem skrze jednotlivé otázky tohoto faktoru, zjistíme, že počet realizovaných cyklů statisticky významně (Sig. $<0,001)$ koreluje - a to záporně - s pocitem, že škola nemá dost znalostí a kvalifikace $k$ provedení autoevaluace, ale také $s$ bezradností ohledně interpretace výsledkủ či s pocitovaným nedostatkem dostupných nástrojů (Spearmanův koeficient korelace je roven $-0,23$, resp. $-0,25$ a $-0,19)$. $V$ těchto třech prípadech jde dokonce o vůbec nejsilnější souvislosti mezi počtem realizovaných cyklů a konkrétními postojovými položkami ${ }^{3}$ (celkem 15). To jen potvrzuje výše zjištěnou největší souvislost mezi počtem cyklů a faktorem bezradnosti, jehož hodnota klesá spolu s rostoucím počtem realizovaných cyklů vlastního hodnocení.

Pro korektnost interpretací však opět připomeňme možné alternativní vysvětlení tohoto - relativně silného - vztahu: školy, které mají „jasno“ v tom, jak vlastní hodnocení školy provést, se do této aktivity poté také častěji pouštějí. Školy, které jsou bezradné a dezorientované, se naopak s větší pravděpodobností vlastnímu hodnocení vyhýbají. Tato interpretace zjištěných souvislostí je stejně korektní jako ta, která říká, že $s$ rostoucími zkušenostmi narůstá také subjektivně pocitovaná schopnost autoevaluaci provádět, což vede k tomu, že se do ní dané školy s větší pravděpodobností skutečně pouštějí.

3 S výjimkou deskriptivní položky „autoevaluaci jsme realizovali před vznikem zákonné povinnosti“ $(r=0,36)$. 
3 Mírně se také ruku v ruce s větší zkušeností škol s vlastním hodnocením zlepšuje "čitelnost" ČŠl a zřizovatelů škol, školám je postupně o trochu jasnější jejich postoj k autoevaluaci. Tento vztah je však relativně velmi slabý (Spearmanův koeficient korelace 0,08 ), těsně za hranicí $5 \%$ statistické významnosti (Sig. $=0,063$ ).

Zajímavé a zásadní je však zjištění, že obě položky - srozumitelnost postoje zřizovatele i ČŠl - sytící tento faktor, samy o sobě souvisí s počtem realizovaných cyklů statisticky signifikantně (Sig. $=0,001$, resp. 0,041 ). Síla tohoto vztahu je však i nadále velmi slabá: v případě postoje ČŠı $(r=0,09)$, jen o něco silnější pak $v$ prípadě srozumitelnosti postoje zřizovatele $(r=0,15)$. Směr závislosti je v obou případech lineární a interpretačně jasný: srozumitelnost postoje těchto institucí $k$ autoevaluaci roste $s$ počtem realizovaných cyklů. $V$ tomto prípadě se totiž jeví alternativní interpretace možného směru vztahu nerealisticky a př́liš šroubovaně (tj. pokud daná škola více "rozumí" postoji ČŠl a zřizovatele k autoevaluaci, častěji ji poté také provádí).

4 Naopak více zkušeností s vlastním hodnocením školy souvisí s výrazným vzestupem názoru, že jde o smysluplnou aktivitu (nedokážou si bez toho představit další zkvalitňování práce školy, učitelé se zajímají o výsledky a chápou to jako smysluplnou aktivitu). Tento vztah je druhý nejsilnější ze všech hodnocených vztahů mezi postojovými faktory a počtem realizovaných cyklů (Spearmanův koeficient korelace 0,21) a je statisticky signifikantní (Sig. <0,001).

Jaké jednotlivé postoje (otázky) k této skutečnosti nejvíce přispívají? S výjimkou zlepšení komunikace s rodiči $($ Sig. $=0,364)$ souvisí statisticky signifikantně počet cyklů se všemi jednotlivými otázkami sytícími faktor smysluplnost (velikost Spearmanova koeficientu korelace se pohybuje v rozmezí 0,14 až 0,16; s konstatováním, že jde o aktivitu, kterou škola realizovala před vznikem legislativního požadavku pak dokonce 0,36 , což však není překvapivé).

5 Podobně také existuje náznak tendence $\mathbf{k}$ mírnému poklesu obav ze zneužití výsledků autoevaluace s rostoucí zkušeností škol. Tento vztah je však velmi slabý (Spearmanův koeficient korelace $-0,05$ ) a co je hlavní, není statisticky významný (spolehlivý, tj. výrazně za hranicí statistické chyby, viz Sig. = 0,474).

Ani jednotlivé otázky sytící tento faktor - strach ze zneužití výsledků a obavy $v$ pedagogickém sboru z postihů - samy o sobě nesouvisí statisticky signifikantně s počtem realizovaných cyklů (Sig. $=0,264$ a 0,121).

\subsubsection{KRAJSKÁ DIFERENCE POSTOJU゚: NEPROKÁZANÁ SOUVISLOST}

Analýza postojů škol k vlastnímu hodnocení z hlediska jednotlivých krajů neodhalila jakoukoliv statisticky signifikantní závislost (ANOVA). Region, kde se škola nachází, nesouvisí s postoji škol k autoevaluaci. Nepozorujeme tedy regiony, kde by panovala větší či menší obava z autoevaluace a jejího zneužití (ANOVA, Sig. = $0,196)$, lepší či horší „čitelnost" ČŠl a zřizovatele (Sig. $=0,135)$, větší či menší přesvědčení o zbytečnosti a neefektivnosti vlastního hodnocení školy (Sig. $=0,545$ ), větší či menší bezradnost ohledně jejího provedení (Sig. = 0,398) nebo snad vyšší 
či nižší přesvědčení o smysluplnosti (Sig. = 0,216). Nejrůznější postoje škol k autoevaluaci jsou tedy distribuovány plošně a rovnoměrně po celém území České republiky. Nepodařilo se identifikovat kraje, kde by např́klad školy k autoevaluaci zastávaly pozitivnější či negativnější postoje.

Regionálně specifické či regionálně zakotvené se mohou z věcného hlediska zdát zejména dva okruhy otázek: (a) srozumitelnost př́istupu k autoevaluaci ze strany zřizovatele a (b) srozumitelnost přístupu k autoevaluaci ze strany České školní inspekce. Ani zde se nepodařilo prokázat statisticky významně odlišnou míru „čitelnosti“ přístupu těchto institucí k vlastnímu hodnocení škol v jednotlivých krajích (ANOVA, Sig. $=0,251$, resp. Sig. $=0,178$ ).

\subsubsection{POSTOJE K AUTOEVALUACI A VELIKOST ŠKOLY: VĚTŠÍ MAJÍ JASNO}

Postoje k autoevaluaci - až na jednu výjimku - nesouvisí s velikostí školy. K tomuto zjištění jsme dospěli jednak zjištováním souvislostí mezi jednotlivými faktory a velikostí školy (ANOVA), jednak korelační analýzou všech postojových otázek (Q 1 až Q 15) a velikosti školy (Spearmanův koeficient korelace, korelační matice). Postoje jsou tedy zhruba podobné u škol malých i těch větších (respektive daný vztah má daleko k linearitě a jakékoliv tendenci k závislosti, viz graf 4).

Postoje k vlastnímu hodnocení školy statisticky spolehlivě souvisí s velikostí školy pouze ve faktoru bezradnosti (ANOVA, Sig. $=0,001$ ). Tato souvislost je opět spíše slabší (Spearmanův koeficient korelace $-0,15)^{4}$. Větší školy si vědí s vlastním hodnocením školy více rady, školy menší naopak méně. Tato analýza naznačuje, že pomoc a expertní podporu při vlastním hodnocení potřebují zejména školy menší velikosti.

Tento vztah snad Ize předběžně vysvětlit tím, že větši školy disponují většími zdroji k provedení vlastního hodnocení (mohou si snáze dovolit vyslat svého zástupce na školení, vlastní administrativní pracovníky, ve větším pedagogickém sboru se spíše vyskytují kvalifikovaní učitelé, kteří jsou schopni autoevaluaci provést atd.).

Jaké konkrétní otázky tvořící tento faktor však k tomuto výsledku vedou? Bližší pohled ukazuje, že statisticky signifikantní vztah existuje pouze mezi velikostí školy a (a) nedostatkem znalostí a kvalifikace pro optimální provedení autoevaluace (Sig. = 0,003, Spearmanův koeficient korelace $-0,14)$, (b) bezradností s interpretací výsledků autoevaluce (Sig. $=0,002$, Spearmanův koeficient korelace $-0,14$ ). Oba tyto vztahy jsou však statisticky velmi slabé; v obou případech spolu s rostoucí velikostí školy mírně klesá její bezradnost (stran nedostatku znalostí a kvalifikace i stran bezradnosti při interpretaci výsledků). Školy všech velikostí pak pocitují zhruba stejně intenzivně nedostatek spolehlivých a volně dostupných nástrojů pro provedení vlastního hodnocení.

4 Podobnou sílu vztahu i statistickou významnost nabízí analýza s kategorizovanou proměnou velikosti školy, ale také s proměnou kardinální (velikost školy udaná nikoliv intervalem, nýbrž číselnou hodnotou vyjadřující počet žáků). 
Graf 4: Velikost školy a postoje $k$ autoevaluaci

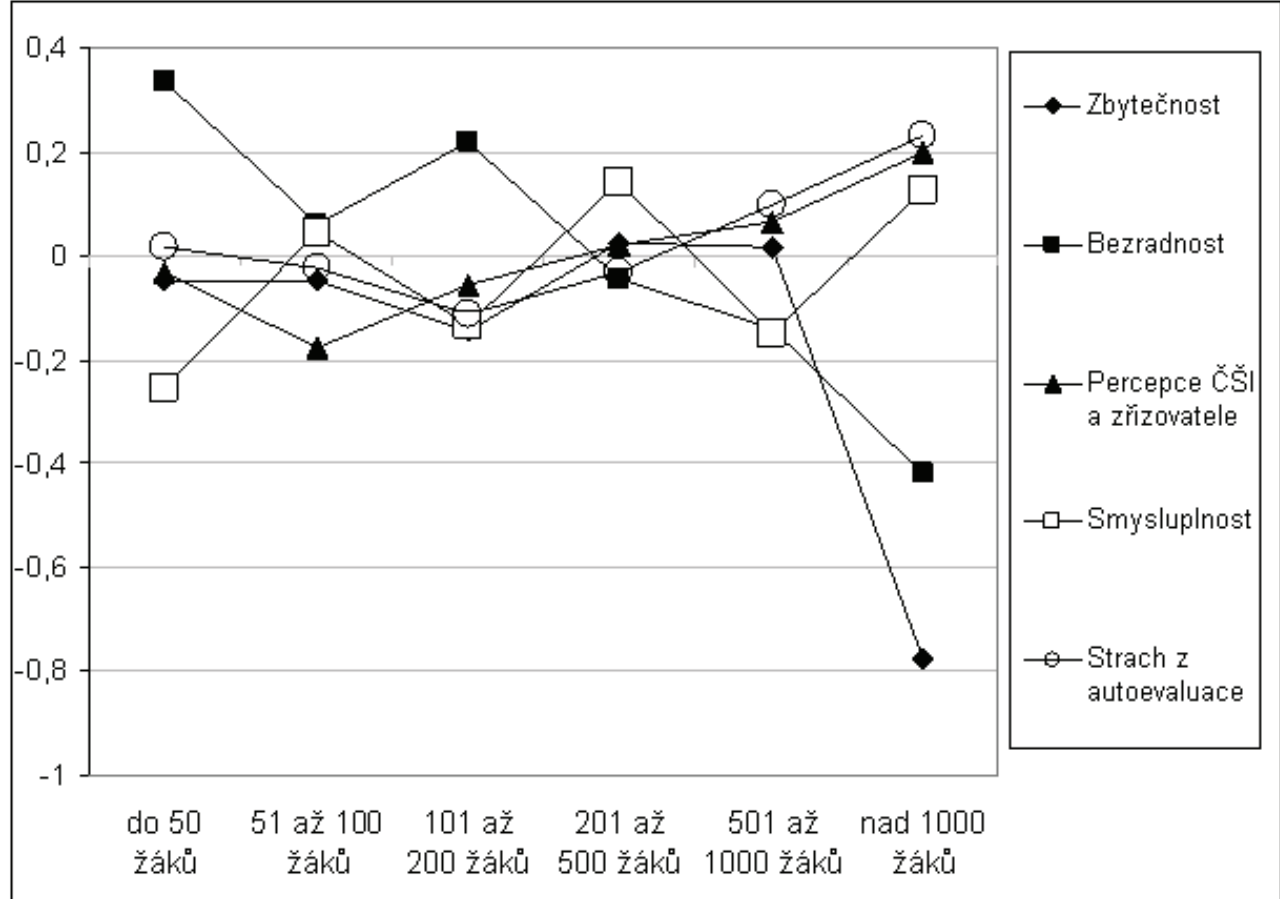

\subsubsection{POSTOJE K AUTOEVALUACI A TYP ŠKOLY}

Při porovnání jednotlivých druhů a typů škol nebyly zaznamenány výraznější interpretovatelné rozdíly. Pouze analýza rozptylu (ANOVA) naznačuje, že postoje $k$ autoevaluaci souvisí s typem školy jen v prípadě bezradnosti (Sig. $<0,006)$.

Základní školy v našem vzorku jsou v oblasti vlastního hodnocení poněkud více bezradné. Oproti tomu střední odborné školy a střední odborná učiliště deklarují, že se necítí při provádění autoevaluace tak bezradné. Zde může být tato souvislost zprostředkovaná i skrze jejich velikost (viz výše).

Tato zjištění byla důvodem pro to, že bylo s výsledky škol pracováno souhrnně.

\subsection{ZÁJEM O AKTIVITY PROJEKTU: SNAHA ZORIENTOVAT SE A „ZATOČIT" S BEZRADNOSTÍ}

Jak již bylo řečeno, školy pocitují relativně vysokou bezradnost ohledně toho, jak realizovat autoevaluaci. S tím souvisí relativně vysoká "poptávka“ po nabízené metodické podpoře a nejrůznějších formách školení a dalších aktivit. Součástí dotazníku byla i nabídka konkrétních aktivit projektu Cesta ke kvalitě s jejich stručným popisem. Školy byly dotázány, zda by měly o tyto aktivity zájem. 
Napríklad celých $86 \%$ škol má zájem o testování a ověřování nabídnutého evaluačního nástroje $s$ tím, že zpět získá výsledky vhodné pro vlastní hodnocení. Necelá polovina škol (43\%) je ochotna zapojit se do podobných aktivit ještě intenzivnějším způsobem, tj. nabídnout, zveřejnit, popsat a sdílet své zkušenosti s vlastním hodnocením.

Velmi vysoký zájem je také o vzdělávací program Koordinátor autoevaluace. Celých $82 \%$ škol by chtělo přihlásit někoho ze svých pedagogických pracovníkủ či $z$ vedení školy do programu. Stejně tak existuje na straně škol vysoká poptávka a zájem o možnost návštěvy poradce pro oblast autoevaluace (75 \%). Školy také deklarují vysoký zájem o zapojení do workshopů na téma autoevaluace (64\%) a o vzájemnou návštěvu škol (51\%). O něco méně o tzv. peer-reviw ${ }^{5}(21 \%)$. Ale vůbec největší zájem byl o zaslání pozvánky na konferenci k problematice autoevaluace $(91 \%)$, která se již uskutečnila v roce 2009 v jednotlivých krajských městech (nezávazná pozvánka sama o sobě ještě samozřejmě automaticky neznamená silný zájem o konferenci jako takovou). Konferencí projektu se zúčatnilo více než 800 zástupců škol (Na cestě ke kvalitě 2009), tedy již o dost více než bylo respondentů dotazníkového šetření (531, z nich se konferencí zúčastnilo 230). Podrobný souhrnný pohled na zájem o nabízené aktivity přináší následující graf 5.

Graf 5: Zájem škol o aktivity projektu Cesta ke kvalitě.

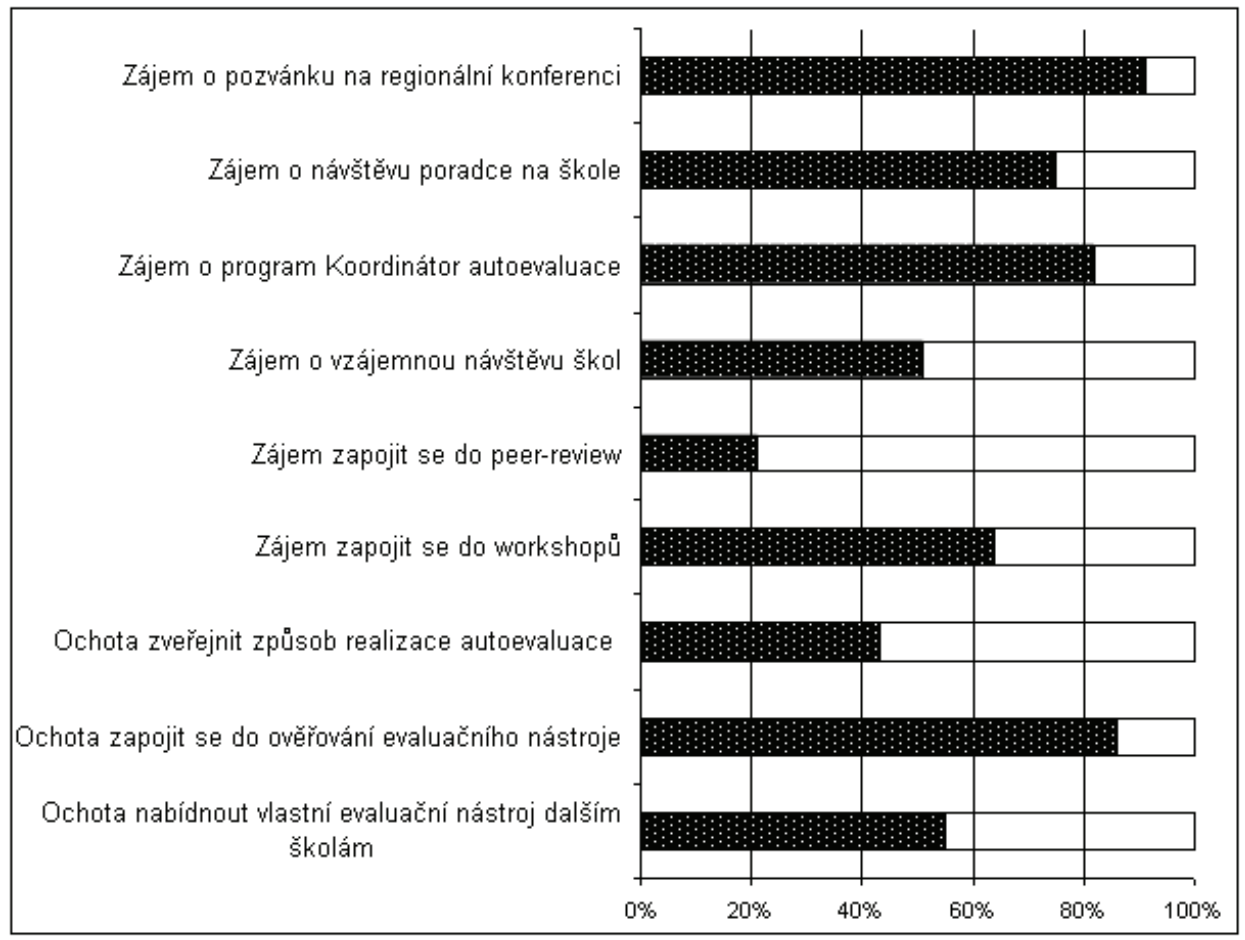

5 Aktivita známá v zahraničí, kdy se školy hodnotí navzájem v bezpečném prostředí bez externího kontrolního orgánu. Tato aktivita předpokládá již poměrně vyspělou úroveň zástupců té školy, která je v roli „kritického př́tele“. 


\section{DISKUSE}

V předloženém textu byly detailně prezentovány výsledky z dotazníkového šetření ředitelů škol od mateřských speciálních, přes základní, všechny typy středních, základních uměleckých škol, konzervatoří až po jazykové školy s právem státní jazykové zkoušky. Oslovena byla celá populace ředitelů těchto škol, ale návratnost byla pouze $8 \%$. Z hlediska vzorku respondentů nebyly zřejmé odchylky od reprezentativity z hlediska typů škol, regionů, velikosti škol. Přesto se nabízí otázka, jaká je výpovědní hodnota (externí validita) výsledků na vzorku s tak malou návratností. Lze se domnívat a výsledky tomu nasvědčují, že na dotazník zareagovaly hlavně dva typy škol: 1) školy, pro které je autoevaluace již delší dobu důležitým tématem a autoevaluaci realizovaly dřive, než jim to bylo uděleno zákonem, 2) školy „zodpovědné", na které dopadl tlak legislativní povinnosti, vzaly ho vážně a chtějí s vlastní bezradností pomoci. $V$ tomto smyslu je potřeba brát velmi obežretně popisné výsledky prezentované v grafech 1, 2 a 5 . Lze se domnívat, že vzhledem $\mathrm{k}$ celé populaci škol jsou tyto výsledky spíše optimistické (srov. s výsledky jiných výzkumů - viz Vaštatková; Prášilová v tomto čísle Orbis scholae).

$\checkmark$ textu jsou prezentovány podrobné výsledky faktorové analýzy, na základě ní bylo identifikováno 5 faktorů a byly nalezeny souvislosti s dalšími proměnnými. Lze se domnívat, že zjištěné vztahy mají univerzálnější charakter a jsou méně ovlivněny sníženou návratností, než popisné výsledky v jednotlivých proměnných samostatně. Vyšší návratnost by se patrně promítla pouze do malých korekcí zjištěných vztahů. Zde pokládáme za zásadní zjištění souvislosti faktorů bezradnosti a chápání smysluplnosti procesů autoevaluace se zkušeností škol odpovídající počtu dosud realizovaných autoevaluačních cyklů. Zjištěné souvislosti jsou pochopitelné a velmi ilustrativní. Interpretace těchto souvislostí ale již tak zřejmá není. $Z$ dat nelze vyčíst, zda nárůst vnímané smysluplnosti a pokles bezradnosti je způsoben narůstající zkušeností (tak bychom si to přáli a Ize ostatní školy takto povzbuzovat), nebo bohatší zkušenost mají právě ty školy, které dříve pochopily smysluplnost autoevaluačních aktivit, samy si s tím poradily v situaci, kdy se jim nedostávalo systematické pomoci. Jinými slovy směr kauzality těchto vztahů je nejasný. $V$ rámci projektu Cesta ke kvalitě se očekává realizace obdobného dotazníkového šetření ke konci projektu na přelomu roku 2011 a 2012. Porovnání výsledků z obou šetření pak může napovědět, jaký je směr této kauzality, případně jak velká procenta škol zapadají do jednoho či druhého směru uvažované kauzality. 


\section{SHRNUTÍ}

České školy (MŠ počínaje a SŠ konče v rámci našeho zorného úhlu) procházejí v posledním desetiletí celou řadou náročných změn (Pol 2007) souvisejících zejména s dopady školského zákona z roku 2004. V roce 2009 byl Ministerstvem školství, mládeže a tělovýchovy ČR schválen projekt Cesta ke kvalitě, který má pomoci školám s nově zavedeným vlastním hodnocením. Dotazníkové šetření realizované na počátku projektu ukázalo, obdobně jako i jiné předcházející výzkumy a šetření, že mezi školami existují velké rozdíly z hlediska potřeby pomoci a že škol, které pomoc potřebují, je stále vysoké procento. Naprostá většina škol si žádá k použití ověrené evaluační nástroje. Ukázala se silná souvislost mezi zkušeností měěenou počtem dosud realizovaných autoevaluačních cyklů a vnímáním smysluplnosti autoevaluace a s mizením bezradnosti. Taktéž se ukázalo, že větší školy jsou méně bezradné. Lze se domnívat, že mají možnost vytvořit volné kapacity pro nové a poměrně specializované činnosti. Projekt Cesta ke kvalitě nabízí celou řadu aktivit, kde se dostane pomoci jak školám, které jsou na samém počátku (vzdělávací program pro koordinátory autoevaluace na školách), tak školám „pokročilým“, které se mohou o své zkušenosti podělit na workshopech, v rámci peer-review, popiší své př́iklady pro ostatní nebo nabídnou své evaluační nástroje k dotváření společně použitelných.

O úspěšnosti projektu a o kauzalitě vztahů mezi zkušeností a postoji k autovevaluaci bude možné ríci více až s dalšími šetřeními. $V$ rámci projektu Cesta ke kvalitě jsou průběžně realizovány rozhovory s řediteli a učiteli, zadávány ankety $v$ určitých obměnách na akcích projektu (workshopy, vzájemné návštěvy škol, peer-review, vzdělávací program pro koordinátora autoevaluace, konference). Jistě bude dobře, když tato šetření budou doplněna i jinými nezávislými výzkumy mimo rámec projektu a hlavně i po jeho ukončení v roce 2012.

\section{LITERATURA}

Autoevaluace mateřské školy. Praha :Tauris, 2008.

Cesta ke kvalitě vede přes vlastní hodnocení. Učitelské noviny, 25/2009.

Chvál, M.; Starý, K. Autoevaluace škol v reflexi poskytované odborné podpory. Orbis Scholae, 2008, roč. 2, číslo 3, s. 53-73.

Konzultačni centrum $k$ realizaci ŠVP ZV v regionech - Závěrečná zpráva z pilotní fáze projektu. Praha : NIDV, 2009.

Macbeath, J.; Schratz, M; Meuret, D.; Jakobsen, L. Serena aneb Autoevaluace škol v Evropě. Ždár nad Sázavou : Fakta, 2006.

Michek, S. Příručka pro sebehodnocení poskytovatelů odborného vzdělávání. Praha : NúOV, 2006.

Michek, S. Přístupy k řízení kvality v odborném vzdělávání. Př́klady pokynů, doporučení, modelů, nástrojů, rámců a standardů kvality z vybraných zemí západní a severní Evropy. Praha : NÚOV, 2008. 
Monitoring implementace kurikulární reformy 2008 - souhrnná zpráva. Praha : ÚlV, 2008 [online] [cit. 2010-3-16]. Dostupné na WWW: <http://www.uiv.cz/clanek/8/1650>.

Na cestě ke kvalitě, 2009, č. 1 [online] [cit. 2010-03-13]. Dostupné na WWW: <http:// www.nuov.cz/ae/1-cislo-bulletinu-projektu-na-ceste-ke-kvalite>.

Pol, M. Škola v proměnách. Brno: MU, 2007.

Prášilová, M.; Vaštatková, J. Determinanty vývoje české základní školy jako učící se organizace. Orbis scholae, 2008, roč. 2, č. 3., s. 23-35.

Průcha, J. Pedagogická evaluace. Brno : MU, 1996.

Příklady dobré praxe pro gymnázia. Praha : VúP, 2008.

Příručka príkladů dobré praxe. Praha :VúP, 2007.

Rýdl, K.; Horská, V.; Dvořáková, M.; Roupec, P. Sebehodnocení školy. Jak hodnotit kvalitu školy. Praha: STROM 1998.

Sborník národního projektu Koordinátor. Praha : NIDV, 2009.

Sborník príspěvků z Metodického portálu www.rvp.cz k tématu autoevaluace. Praha: VúP, 2007 [online] [cit. 2010-03-13]. Dostupné na WWW: <http://www.rvp.cz/ clanek/804/1769>.

Starý, K. Autoevaluace školy. Praha : NúOV, 2005.

Vaštatková, J. Úvod do autoevaluace školy. Olomouc : UP, 2006.

Vaštatková, J.; Prášilová, M. Možné podoby autoevaluace ve školách. Orbis scholae, 2010, roč. 4, č. 1.

Výsledky dotazníkového šetření v projektu Cesta ke kvalitě v roce 2009 [online] [cit. 2010-03-19]. Dostupné na WWW: <http://www.nuov.cz/ae/vystupy-projektu>. 